\title{
The Service Information System Web-Based Of Maternity Clinic In BKIA Rakyat
}

\author{
$1^{\text {st }}$ Indri Anugrah Ramadhani ${ }^{1}, 2^{\text {nd }}$ Asrul $^{2}$ \\ \{indianugrah18@gmail.com ${ }^{1}$, asrulidrus18@gmail.com² \\ Universitas Pendidikan Muhammadiyah Sorong, West Papua, Indonesia ${ }^{1,2}$
}

\begin{abstract}
The purpose of this study is to design service information in the BKIA Rakyat Maternity Clinic which is expected to provide the ease way to patient in conducting consultation and nursing and also to provide convenience to the officer in the data collection of patient and payment transaction process. The study was conducted in the BKIA Rakyat Maternity Clinics which was held for one month, from February to March 2015. The methodology used in the design of Web-based Maternity Clinic service information systems is the prototyping method. The result obtained from the design of service information system in the Web-based Maternity Clinic is a Web-based information system that can improve the quality and performances of BKIA Rakyat Maternity Clinic. From the result of trials and application validation on each respondent, it was conclude that the quality of application of Web-based patient data information system was good. Then the trial result of using the Black box and White box testing concluded that the system is feasible to use.
\end{abstract}

Keywords: Service Information System, Prototyping, PHP, MySQL, BKIA Maternity Clinic

\section{Introduction}

The development of technology in the world today is growing rapidly, including in terms of the utilization of information technology related to information systems. Every company needs fast, accurate and precise information. The information continues to flow and the longer the number is increasing along with the number of data requests, as well as the increasing amount of data so that a database is required to accommodate the data.

Health is one of the indicators of successful development organized by a country. Health is a prosperous state of body, soul and social that allows every person to live socially and economically productive lives. To meet the health needs of the community, the government seeks to provide health facilities and infrastructure, one of which is by building a maternity house.

Maternity House is a service business unit that provides social services in clinical medical field, in the era of globalization nowadays, maternity home is required to improve performance and competitiveness as a business entity by not reducing the mission The Social.

The most common problem is in the process of service and data storage. Officers often take a long time to find a data. In addition, a patient has to wait a long time because of administrative affairs, this resulted in many queues of patients in conducting care and consultation. The demands of information services for patients in maternity homes are 
increasing, so the service system should be improved in accessing the information needed by the patient in order to facilitate in various actions, such as data retrieval, Consultation, and administration process. Based on the above explanation to improve the better service to the author's patients interested to compose the final task with the title. "Information systems services on the BKIA Rakyat maternity House". In hopes it can help and improve the function of BKIA Rakyat Maternity House as a place of health care.

\section{Literature Review}

\section{PHP}

Peranginangin. 2006: 2 that PHP an acronym for Hypertext Preprocessor which is used as a server-side scripting language in developing web embedded in HTML documents. The use of PHP allows the web to be made dynamic so that maintenance of the website becomes easier

and more efficient. The program / script syntax is written in PHP Special signature.

Mysql

According to Nugroho (2009: 1), MySQL is a database server program that is capable of receiving and sending data very quickly, multi-user, and using standard SQL commands. MySQL is a Free Software under the GNU / GPL (General Public License).

MySql uses a standard format SQL (Structure query language) which is a language that contains commands to manipulate the data base, starting from performing select commands to display the contents of the data base, insert or add content to the data base, delete or delete the contents of the data base and editing data base. In SQL there are several important component elements, first DDL (Data Definition Language) is a statement relating to the creation of objects and processing structures. The two DML (Data Manipulation Language) are statements related to manipulating data in tables. Third DCL (Data Control Language) are control statements such as commit and rollback.

\section{Data Flow Diagram (DFD)}

According is Jogiyanto, 2005. Data Flow Diagrams (DFD) are diagrams that use symbol notation to describe the data flow system. Sutanta, 2003 DFD is the logic design of a system that describes in detail the sequence of steps of each process described in the data flow diagram

\section{Method}

The research is research and development $(\mathrm{R} \& \mathrm{D})$. Research and Development $(\mathrm{R} \& \mathrm{D})$ is a series of processes or steps that can be used to develop a new product or improve existing products so that they can be reported. Development is the process of translating design specifications into physical forms related to the design, development, and evaluation processes of systematic learning, with the aim of establishing an empirical basis for the creation of new products or models. learning and non-learning aimed at improving existing development. (Richey, 2007). 
Data collected by holding a question and answer session with the interviewed sources to obtain the required data. This question and answer is done directly with the respondent as the informant, and from that respondent will ask directly what is relevant and related to the object under study.

\section{Design Models}

This system development is by using the development model contained in the prototyping development method. The prototyping model is the process of making a simple model for the final software that allows the user to have a basic overview of the program and conduct initial testing. (Mulyani, 2009)

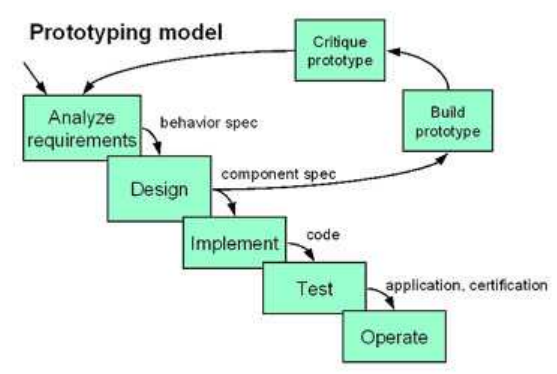

Figure 1. Prototyp Model

\section{Design System}

Software design is done after the needs analysis phase is completed where this design will be divided into several sections, including:

Diagram context;

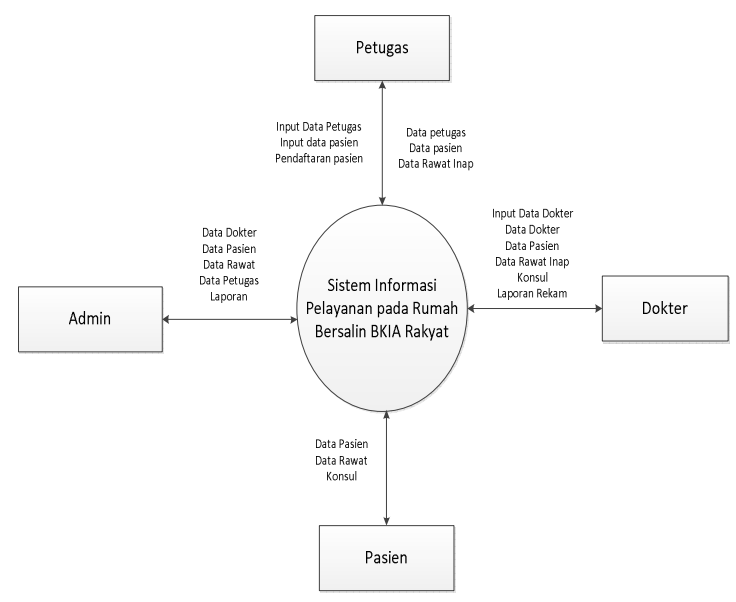

Figure 2. Diagram Context 


\section{Results and Discussion}

The results of this research are in the form of a system designed with the PHP (Hypertext Preprocessor) programming language and MySql database to form a maternity care system in BKIA Rakyat. Patients can access the maternity hospital profile online, register their own registration, and can consult a doctor without having to come to the maternity hospital, also can more easily make payment transactions. Comparison of the old service system to the new service system, as shown in table 1.

Table 1. Implementation of Maternity Hospital Service System

\begin{tabular}{lll}
\hline Difference & Old System & System Now \\
\hline process & Conventional & Online Based \\
Client & Human & Computer \\
\hline
\end{tabular}

The system implementation is done after the system is validated by a validator with results that are in the good category, then the service system is implemented at the BKIA Rakyat Maternity Hospital by showing the officers, the head of the maternity hospital and patients. The main page is the page that will appear on maternity hospital service information system applications. The main page contains a menu of process options that can be done by the system, as in Figure 2

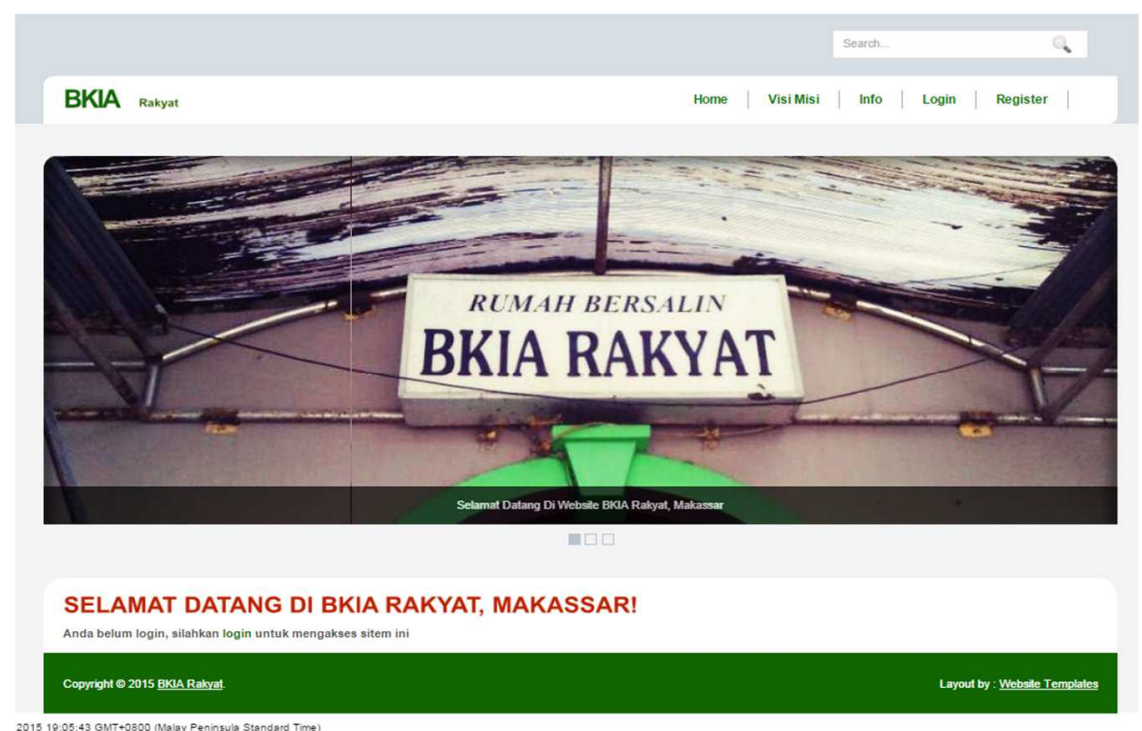

Figure 3. Home Page 


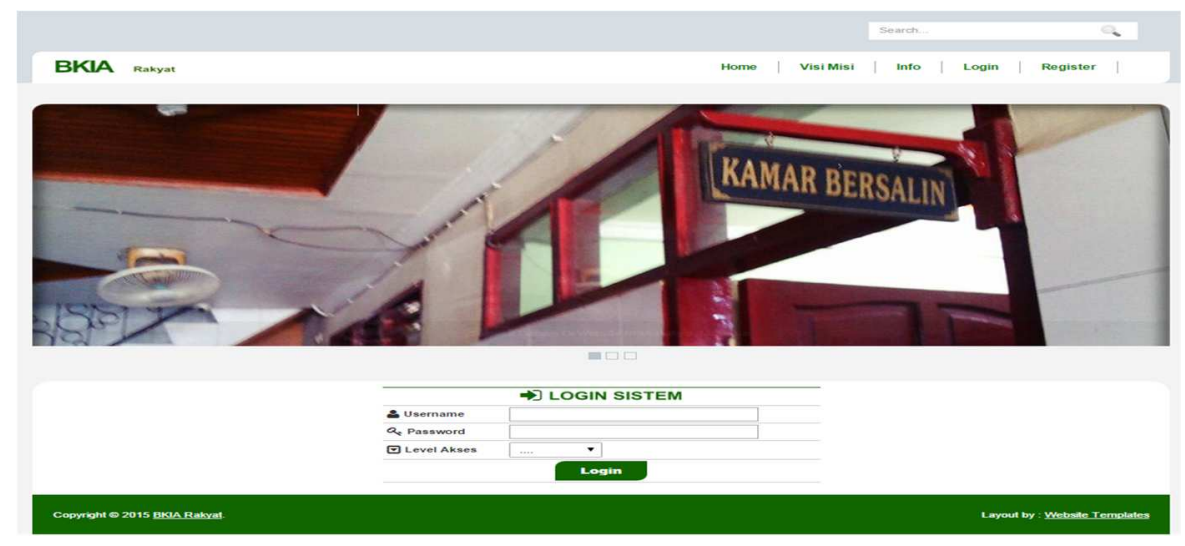

Figure 4. Menu Login

\section{Conclusion}

Based on the results of the design and testing of a maternity home service system in the web-based BKIA Rakyat, it can be concluded that the maternity home information service system in the web-based BKIA Rakyat is designed using a prototyping model and produces a prototype that is suitable for use. Service Information System at BKIA People's Maternity Hospital is able to provide accurate registration, consultation and data collection services as well as providing facilities and menus for officers in the process of payment transactions and printing out patient payment results.

\section{References}

[1] Somov, A.: Wildfire safety with wireless sensor networks. EAI Endorsed Transactions on Ambient Systems. pp. 1-11 (2011)

[2] Motaz, A.: Start programming using Object Pascal. Vol. 2, pp. 10-11. Legally Free Computer Books, US (2013)

[3] Abdul Kadir.: Dasar Pemrograman Web Dinamis Menggunakan PHP. Yogyakarta: Andi. (2008)

[4] Abdul Kadir, 2008. Pengenalan Sistem Informasi Yogyakarta : Andi.

[5] Adi Nugroho. 2009. Rekayasa Perangkat Lunak Menggunakan UML dan Java. Yogyakarta : Andi

[6] Alin Elif, 2010. Pengertian Sistem Menurut Para Ahli [online], (https://www.academia.edu/7534109/Pengertian_Sistem_Menurut_Jogiyano_H), diakses tanggal 9 Januari 2015

[7] Amir, 2011. Perancangan Sistem Informasi.[pdf], (http://repository.amikom.ac.id/files/NASKAH\%20PUBLIKASI_06.12.1506.pdf), diakses tanggal 9 Januari 2015.

[8] Andi Pahri, 2011. Metode Pengembangan Perangkat Lunak [pdf], (http://www.academia.edu/4844015/Metode_pengembangan_perangkat_lunak), diakses tanggal 9 Januari 2015. 
[9] Anjar Mustika, 2010. Kesehatan adalah Keadaan Sejahtera dari Badan [online], (http://www.academia.edu/8361550/Kesehatan_adalah_keadaan_sejahtera_dari_badan), diakses tanggal 24 Maret 2015

[10] Budi Raharjo, 2012. Modul Pemrograman Web (HTML, PHP, dan MySql). Yogyakarta.. [11] Bunafit Nugroho, 2014. Membuat Aplikasi Web klinik apotek. D.i. Yogyakarta: PT. Alif Media.

[12] Edhy Sutanta. 2003. Sistem Informasi Manajemen. Graha Ilmu. Yogyakarta.

[13] Erna Sulistiani, 2012. Sistem Informasi Kesehatan Ibu dan Anak. [pdf],

(http://repository.amikom.ac.id/files/Publikasi 09.12.3510.pdf), diakses tanggal 9 Januari 2015.

[14] Etty Ernawati, 2011. Pengembangan Sistem Informasi Rumah Sakit (Simr)

Untuk Meningkatkan Kualitas Pelayanan [doc],

(https://www.academia.edu/8218698/Pengembangan_Sistem_Informasi_Rumah_Sakit_Simr_Untuk_ Meningkatkan Kualitas Pelayanan), diakses tanggal 9 Januari 2015

[15] Farhan Inung, 2014. Metode Prototyping Dalam Pengembangan Sistem Informasi [online], (http://inungandthenotes.blogspot.com/2014/06/metode-prototyping-dalam-pengembangan.html), diakses tanggal 9 Januari 2015

[16] Farid, 2003. Pengantar Database, IlmuKomputer [online],

(http://ilmukomputer.org/category/database/), diakses tanggal 10 Januari 2015

[17] Gordon, B.Davis, 2002, Kerangka Dasar Sistem Informasi Manajemen, PPM, Jakarta.

[18] Indra Bastian, 2007, Akuntansi untuk LSM dan Partai Politik, Yogyakarta.

[19] Jogiyanto,HM. 2005. Analisis dan Desain Sistem Informasi. Yogyakarta: Andi Offset.

[20] Jovan, FN, 2007, Panduan Praktis Membuat Web dengan PHP untuk pemula. Jakarta Selatan : Media Kita.

[21] Maria K, 2006. Analsis dan Perancangan Basis Data pada Unit Rehabilitasi Medik Rumah Sakit [pdf], (http://eprints.binus.ac.id/338/1/2006-2-01136-IF-Abstrak), diakses tanggal 9 januari 2015

[22] Raymond McLeod,Jr. 2001. Sistem Informasi Edisi 7 Jilid 2. Prenhallindo. Jakarta), Bandung: Alfabeta.

[23] Sri Mulyani, NS Ak, 2007, Metode Analisis dan Perancangan Sistem. Bandung : Abdi Sistematika.

[2] Paryati and Yosef Murya Kusuma Ardhana, 2008, Sistem Informasi. Yogyakarta: Ardana Media.1, No. 1.

[24] Peranginangin, Kasiman. 2006. Aplikasi WEB dengan PHP dan MySQL, Yogyakarta: Andi. 